\title{
NILAI KARAKTER PADA MATA PELAJARAN PAI DALAM KURIKULUM 2013

\author{
(Analisis Buku Siswa Tingkat 1 di Sekolah Dasar)
}

\author{
Juli Amaliya Nasucha \\ Institut Pesantren KH Abdul Chalim Mojokerto \\ amel.cemalcemil53@Gmail.com
}

\begin{abstract}
The character which contained in the students' handbook in class 1 $P A I$ subjects is compulsory learning resources for the implementation of the 2013 curriculum because basically handbook can transform knowledge and life values related to Core Competence (Kompetensi Inti (KI)) and Basic Competence (Kompetensi Dasar (KD)) taught. Therefore the students' handbook published by the government needs to be analyzed first. This study aims to analyze the content of character values and suitability of character education contained in the student handbook with KI and KD contained in the students' handbook on Islamic Education and Character subjects in Elementary Schools in the 2013 Curriculum using library research. The results of the study indicate that the character education content which exists in class I Islamic Education handbook has 20 character values.
\end{abstract}

Keywords: Character Value, Islamic Education, 2013 Curriculum.

Nazhruna: Jurnal Pendidikan Islam

Vol. 2 No 1 2019. Issn: 2614-8013. Hal. 108-135

DOI: $10.3153 /$ nzh.v2i1.234 


\section{Abstrak}

Nilai karakter yang tercantum pada buku siswa mata pelajaran PAI kelas I merupakan sumber belajar wajib pada implementasi kurikulum 2013 ini, karena pada dasarnya buku siswa dapat mentransformasikan ilmu pengetahuan dan nilai-nilai kehidupan yang berkaitan dengan kompetensi Inti dan Kompetensi Dasar yang diajarkan. Oleh karena itu buku siswa yang diterbitkan oleh pemerintah perlu dianalisis terlebih dahulu. Penelitian ini bertujuan untuk menganalisis muatan nilai karakter dan kesesuaian pendidikan karakter yang tertuang dalam buku siswa dengan $\mathrm{KI}$ dan $\mathrm{KD}$ yang terdapat dalam buku siswa mata pelajaran Pendidikan Agama Islam dan Budi Pekerti di Sekolah Dasar dalam kurikulum 2013 dengan menggunakan penelitian kepustakaan (Library research). Adapun hasil penelitian menunjukkan bahwa muatan pendidikan karakter yang tercantum pada buku pendidikan Agama Islam kelas I terdapat 20 nilai karakter.

Kata Kunci: Nilai Karakter, Pendidikan Agama Islam, Kurikulum 2013.

\section{Pendahuluan}

Perubahan keadaan zaman saat ini begitu pesat, hal ini mengakibatkan banyaknya dampak-dampak positif maupun negatif yang bermunculan terutama terkait persoalan moral. Diberbagai media sosial banyak dijumpai postingan yang memperlihatkan tindak kekerasan, tawuran antar remaja dan perilaku-perilaku yang merusak diri seperti penyalahgunaan narkoba, pelecehan seksual hingga berani memosting foto maupun video dirinya sendiri dalam keadaan setengah telanjang. Dari semua persoalan moral ini, yang lebih memprihatinkan yakni pelaku dari tindakan tersebut dilakukan oleh para remaja dan anak-anak yang masih dalam usia yang sangat belia.

Beberapa fenomena di atas disebabkan pada hilangnya karakter pada diri seorang siswa. Moral anak tidak akan rusak ketika dia memiliki karakter 
yang kuat. Pada hakekatnya pendidikan karakter/moral memiliki dua tujuan, yaitu membantu manusia untuk menjadi pintar (smart), dan baik (good). ${ }^{1}$ Dalam riwayat sebuah hadist Nabi Muhammad Saw. juga menegaskan bahwa misi utamanya dalam mendidik manusia adalah untuk menyempurnakan akhlak dan mengupayakan pembentukan karakter yang baik (good character). ${ }^{2}$ Menjadikan manusia pintar, boleh jadi mudah melakukannya, tetapi menjadikan manusia agar menjadi orang yang baik dan bijak, tampaknya jauh lebih sulit atau bahkan sangat sulit. Maka dari itu seorang pendidik tidak hanya dituntut menjadi pengajar tetapi sekaligus mendidik yakni dengan memberikan nilai-nilai moral baik pada siswa yang di mulai sejak ia dini.

Oleh sebab itulah kemudian pemerintah menurunkan kebijakan pergantian kurikulum dari KTSP menjadi Kurikulum 2013. Kurikulum 2013 ini lebih menekankan pada penanaman karakter dan budaya kepada siswa yang dimulai sejak usia dini. ${ }^{3}$ Dalam strategi implementasinya pemerintah menyediakan buku siswa dan buku guru sebagai buku wajib sumber belajar di sekolah. Buku tersebut diluncurkan berupa cetak dan E-book. Buku selain sebagai sarana untuk mentransformasikan pengetahuan di dalamnya juga termuat nilai-nilai karakter agar tercapainya tujuan dari tiap pembelajaran.

Ditinjau dari fungsi dan peranan buku teks yang sangat berpengaruh dalam hasil pembelajaran, maka buku tersebut harus memiliki kualitas yang baik. Semakin baik kualitas buku pelajaran, maka semakin sempurna pengajaran mata pelajaran yang ditunjangnya. Buku ajar yang dapat dikatakan baik yaitu buku yang materi/isi dalam buku siswa sesuai dengan pendidikan karakter tuntutan kurikulum yang berkaitan dan berkualitas, mengacu pada sasaran yang akan dicapai peserta didik yakni kesesuain antara KI dan KD, berisi informasi, pesan, pengetahuan yang dituangkan dalam bentuk tertulis yang dapat dikomunikasikan kepada pembaca, konsep-konsep disajikan secara menarik dan interaktif, tehknik penulisan yang sesuai dengan kebenaran bahasa (pengukuran kebenaran bahasa ini dilakukan dengan cara membandingkan penggunaan bahasa yakni meliputi: tanda baca, kosa kata,

${ }^{1}$ Ali Maksum, Pluralisme dan Multikulturalisme Pradigma Baru Pendidikan Agama Islam di Indonesia, (Malang: Aditya Media Publising, 2011), 8.

2 Abdul Majid, Pendidikan Karakter Perspektif Islam, (Bandung: PT. Rosda Karya, 2011), 2 .

3 Ngainun Naim, “Character Building” (optimalisasi peran pendidikan dalam pengembangan ilmu \& pembentukan karakter bangsa), (Yogyakarta: Ar-Ruzz Media, 2012), 40. 
kalimat, dan paragraf. dengan Ejaan Yang Disempurnakan (EYD), dan tersaji dalam wujud tampilan yang menarik.

Buku ajar Pendidikan Agama Islam dan Budi Pekerti tingkat 1 pada kurikulum 2013 yang disediakan oleh pemerintah untuk keperluan skala nasional merupakan "dokumen hidup" yang senantiasa diperbaiki, diperbaharui, dan dimutakhirkan sesuai dengan dinamika kebutuhan dan perubahan zaman ${ }^{4}$. Oleh sebab itu perlu mencermati terlebih dahulu muatan buku siswa maupun buku pegangan guru yang sudah disediakan pemerintah. Jika menemukan buku sumber pengajaran dan pendidikan yang mengandung kata-kata tidak pantas/bahasa yang tidak sopan, tidak boleh dianggap sepele. Sebab, jika tidak diperhatikan, hal itu sama saja mencederai kurikulum yang mengedepankan pendidikan karakter.

Terkait dengan latar belakang tersebut, maka penulis tertarik untuk menganalisis muatan karakter yang termuat dalam isi buku dan kesesuaian nilai karakter yang tertuang dalam buku siswa dengan KI dan KD Pendidikan Agama Islam dan Budi Pekerti tingkat 1 Sekolah Dasar.

\section{Metode Penelitian}

Penelitian ini termasuk jenis penelitian kepustakaan (library reseach). Penelitan tersebut merupakan serangkaian kegiatan yang berkenaan dengan metode pengumpulan data pustaka, membaca dan mencatat serta mengolah data penelitian tentang pendidikan karakter dalam kurikulum 2013 (analisis buku siswa mata pelajaran Pendidikan Agama Islam dan Budi Pekerti di Sekolah Dasar). ${ }^{5}$

Melihat dari segi sifatnya, penelitian ini termasuk pada penelitian kualitatif, ${ }^{6}$ yang mana jenis penelitian ini digunakan untuk mendapatkan data dalam menyusun teori-teori pendidikan karakter kurikulum 2013 sebagai landasan ilmiah untuk mengkaji dan menelaah buku siswa mata pelajaran Pendidikan Agama Islam dan Budi Pekerti di Sekolah Dasar dengan permasalahan bagaimana muatan pendidikan karakter dan kesesuaian pendidikan karakter yang tertuang dalam buku siswa dengan $\mathrm{KI}$ dan $\mathrm{KD}$ mata pelajaran Pendidikan Agama Islam dan Budi Pekerti di Sekolah Dasar.

\footnotetext{
${ }^{4}$ Kementrian Pendidikan dan Kebudayaan, Pendidikan Agama Islam dan Budi Pekerti, ii. ${ }^{5}$ Mestika Zed, Metode Penelitian Kepustakaan, (Jakarta: Yayasan Obor Indonesia, 2004), 3.

${ }^{6}$ Sudarwan Danim, Menjadi Peneliti Kualitatif, (Bandung: CV. Pustaka Setia, 2002), 60. 


\section{Sumber Data}

a. Sumber primer

Data primer yaitu data yang langsung dan segera dapat diperoleh dari sumber data oleh penyelidik untuk tujuan yang khusus. ${ }^{7}$ Atau dengan kata lain data ini meliputi bahan yang langsung berhubungan dengan pokok-pokok permasalahan yang menjadi objek penelitian ini, yaitu buku siswa mata pelajaran Pendidikan Agama Islam dan Budi pekerti kelas I \& IV di Sekolah Dasar (SD) yang diterbitkan oleh Kementrian Pendidikan dan Kebudayaan tahun $2013^{8}$.

b. Sumber sekunder

Data yang dimaksud adalah berbagai bahan yang tidak langsung berkaitan dengan objek dan tujuan dari pada penelitian ini, bahan tersebut diharapkan dapat melengkapi dan memperjelas data-data primer. ${ }^{9}$ Data ini berupa buku-buku, artikel, dan naskah yang berisi tentang hakikat pendidikan karakter, pengembangan dan implementasi kurikulum 2013, hakikat pendidikan islam, dan hakikat buku ajar. Serta secara fungsional berguna untuk menunjang kelengkapan data primer.

\section{Teknik Pengumpulan Data}

Pengumpulan data merupakan salah satu tahapan sangat penting dalam penelitian. Teknik pengumpulan data yang benar akan menghasilkan data yang memiliki kredibilitas tinggi. Maka dari itu sesuai prosedur dan ciri-ciri penelitian kualitatif metode pengumpulan data yang dipakai dalam penelitian ini adalah metode dokumentasi, yakni dengan mencari atau mengumpulkan data mengenai pendidikan karakter kurikulum 2013 dalam berupa buku, artikel dan surat kabar, jurnal dan sebagainya.

Adapun langkah-langkah yang dapat ditempuh peneliti sebagai upaya menyelaraskan metode dokumentasi tersebut, antara lain:

\footnotetext{
${ }^{7}$ Winarno Surakhman, Pengantar Penelitian Ilmiah, (Bandung: Tarsito, 1994), 163.

${ }^{8}$ Kementrian Pendidikan dan Kebudayaan, Pendidikan Agama Islam dan Budi Pekerti, (Jakarta: Kementrian Pendidikan dan Kebudayaan, 2013), ii.

${ }^{9}$ Sutrisno Hadi, Metodologi Research, (Yogyakarta: Andi Offset, 1989), 53.
} 
a. Reading, membaca dan mempelajari literature-literatur yang berkenaan tentang hakikat pendidikan karakter, pengembangan dan implementasi kurikulum 2013, hakikat pendidikan islam, hakikat buku ajar, buku ajar siswa pendidikan agama islam dan budi pekerti kelas I \& IV di Sekolah Dasar, dan hubungan buku siswa pendidikan agama islam dan budi pekerti dengan pendidikan karakter implementasi kurikulum 2013. Sebagai awal dari proses pengumpulan data.

b. Writing, membuat catatan data yang tertulis tentang muatan pendidikan karakter dan kesesuaian pendidikan karakter yang tertuang dalam buku siswa dengan KI dan KD yang terdapat dalam buku siswa mata pelajaran Pendidikan Agama Islam dan Budi Pekerti di Sekolah Dasar, melalui instrument: ${ }^{*}$ format instrumen terlampir.

c. Cheking, ${ }^{10}$ memilih, menyeleksi dan memeriksa validitas data/keakuratan data yang diperoleh dari analisis tentang muatan pendidikan karakter dan kesesuaian pendidikan karakter yang tertuang dalam buku siswa dengan KI dan KD yang terdapat dalam buku siswa mata pelajaran Pendidikan Agama Islam dan Budi Pekerti di Sekolah Dasar, sehingga hanya yang relevan saja yang digunakan dalam analisis.

d. Editing, ${ }^{11}$ data yang telah diteliti secara cermat, perlu diedit yakni dibaca kembali dan diperbaiki bila dijumpai adanya kesalahan atau permasalahan dengan segera melakukan penjelasan dan klarifikasi dari semua catatan data yang telah dihimpun. Langkah ini menuntut kejujuran/kebenaran data tentang muatan pendidikan karakter dan kesesuaian pendidikan karakter yang tertuang dalam buku siswa dengan KI dan KD yang terdapat dalam buku siswa mata pelajaran Pendidikan Agama Islam dan Budi Pekerti di Sekolah Dasar, sehingga data tersebut sesuai dan konsisten dengan rencana risetnya

e. Keseluruhan data tentang muatan pendidikan karakter dan kesesuaian pendidikan karakter yang tertuang dalam buku siswa dengan KI dan KD yang terdapat dalam buku siswa mata pelajaran Pendidikan Agama Islam dan Budi Pekerti di Sekolah Dasar yang sudah terkumpul

\footnotetext{
${ }^{10}$ Kasiram, Metodologi Penelitan; Refleksi Pengembangan Pemahaman dan Penguasaan Metodologi Penelitian, (Bandung: CV. Pustaka Setia, 2000), 53.

${ }^{11}$ Restu Kartiko Widi, Asas Metodologi Penelitian, (Yogyakarta: Graha Ilmu, 2010), 225 .
} 
kemudian dianalisis, yang dimulai dengan menelaah seluruh data yang tersedia dalam berbagai sumber.

\section{Teknik Analisis Data}

Tahapan yang penting dalam penyelesaian suatu kegiatan penelitian ilmiah adalah tahap analisis data. Analisis data adalah proses penghimpunan atau pengumpulan, pemodelan dan transformasi data dengan tujuan untuk menyoroti dan memperoleh informasi yang bermanfaat, memberikan saran, kesimpulan dan mendukung pembuatan keputusan. ${ }^{12}$ Tanpa dianalisis data menjadi tidak bermakna/mati/tidak berbunyi. Oleh karena itu analisis data ini untuk memberi makna dan nilai yang terkandung dalam data.

Adapun tehnik analisis data dari penelitian ini adalah menggunakan instrument analisis deduktif dan content analysis atau analisis isi. Dengan menggunakan analisis deduktif, langkah yang penulis gunakan dalam penelitian ini ialah dengan cara menguraikan beberapa data yang bersifat umum yang kemudian ditarik keranah khusus atau kesimpulan yang pasti. ${ }^{13}$

Sedangkan Content Analysis atau kajian isi menurut Holsti sebagaimana dikutip oleh Lexy J. Moleong, adalah teknik apapun yang digunakan untuk menarik kesimpulan melalui usaha menemukan karakteristik pesan, dan dilakukan secara objektif dan sistematis. ${ }^{14}$

Content analysis/analisa isi dalam penelitian ini digunakan untuk pengolahan data dari Buku Siswa Pendidikan Agama Islam dan Budi Pekerti Kelas I Dan IV Sekolah Dasar. Aspek yang dianalisis meliputi 1) muatan pendidikan karakter yang terdapat dalam buku siswa, 2) kesesuaian pendidikan karakter yang tertuang dalam buku siswa dengan KI dan KD. Kedua hal tersebut diperjelas melalui teknik pemaparan nilainilai pendidikan karakter dari segi materi (teoritik, contoh/ kisah teladan, kesesuaian dengan tingkat perkembangan/umur peserta didik), visualisasi

\footnotetext{
${ }^{12}$ Restu Kartiko Widi, Asas Metodologi Penelitian, 251.

13 Cholid Narbuko dan Abu Ahmadi, Metodologi Penelitian, (Jakarta: Bumi Aksara, 2009), 18.

${ }^{14}$ Burhan Bungin, Metodologi Penelitian Kualitatif, (Jakarta: PT Raja Grafindo Persada, 2006), 220
} 
(gambar), Tugas/latihan (Self assessement (penilaian diri), Angket, dan latihan) yang terdapat dalam buku siswa mata pelajaran Pendidikan Agama Islam dan Budi Pekerti di Sekolah Dasar.

Dalam hal ini penulis menggunakan prosedur analisis membahas dari beberapa data kemudian dideskripsikan. Selanjutnya dikelompokan dengan data yang sejenis, dan dianalisa isi buku siswa mata pelajaran Pendidikan Agama Islam dan Budi Pekerti di Sekolah Dasar secara kritis guna mendapatkan formulasi yang kongkrit dan memadai, sehingga pada akhirnya penulis pergunakan sebagai langkah dalam mengambil kesimpulan sebagai jawaban dari rumusan masalah bagaimana muatan pendidikan karakter yang terdapat dalam buku siswa mata pelajaran Pendidikan Agama Islam dan Budi Pekerti di Sekolah Dasar dalam kurikulum 2013 dan bagaimana kesesuaian pendidikan karakter yang tertuang dalam buku siswa dengan KI dan KD mata pelajaran Pendidikan Agama Islam dan Budi Pekerti di Sekolah Dasar. ${ }^{15}$

Maksud penulis dalam penggunanaan teknik content analysis ialah untuk mempertajam maksud dan inti data-data tentang muatan pendidikan karakter dan kesesuaian pendidikan karakter yang tertuang dalam buku siswa dengan KI dan KD mata pelajaran Pendidikan Agama Islam dan Budi Pekerti di Sekolah Dasar yang diterbitkan oleh Kementrian Pendidikan dan Kebudayaan di Jakarta tahun 2013. ${ }^{16}$

\section{Hasil dan Pembahasan}

Gambaran Isi Buku Siswa Pendidikan Agama Islam dan Budi Pekerti Kelas I

Buku Pendidikan Agama Islam dan Budi Pekerti kelas I Sekolah Dasar (SD) cetakan I diterbitkan oleh Kementrian Pendidikan dan Kebudayaan. Tim penyusun di antaranya Achmad Hasim, Otong Jaelani (Kontibutor naskah),Yusuf A., Ismail SM. (penelaah), Politeknik Negeri Media Kreatif (penyelia penerbitan). Disusun menggunakan huruf/font Bear

\footnotetext{
15 Noeng Muhajir, Metodologi Penelitian Kualitatif, (Yogyakarta: Raka Sarasin, 2000), 68.

${ }^{16}$ Kementrian Pendidikan dan Kebudayaan, Pendidikan Agama Islam Dan Budi Pekerti, ii.
} 
Metonia dengan ukuran font 16 pt. Dicetak dan diterbitkan pada tahun 2013 di Jakarta, terdiri dari 76 halaman.

\section{Sistematika}

Sistematika buku Pendidikan Agama Islam kelas I Sekolah Dasar (SD), yaitu dimulai halaman sampul atau cover, catalog dalam, kata pengantar, daftar isi, isi, dan daftar pustaka.

Adapun sistematika penyajian isi buku tersebut dimulai dengan mengamati dan menceritakan gambar, pembahasan materi (terdiri dari uraian materi pokok, berbagai kegiatan pembelajaran misalnya membaca, menghafalkan, melafalkan surat pendek, bersholawat, diskusi, dan lainlain), rangkuman, dan latihan soal.

\section{Isi Pokok Bahasan}

Isi (materi) pokok bahasan buku pelajaran Pendidikan Agama Islam kelas I (SD) meliputi 11 sub bahasan pelajaran, adalah sebagai berikut: ${ }^{17}$

a. Pelajaran 1 materi Kasih Sayang

1) Kasih sayang nabi Muhammad SAW,

2) Kasih sayang Allah SWT.

b. Pelajaran 2 materi Aku Cinta Al-Qur'an

1) Membaca basmalah,

2) Melafalkan surah al-Fatihah,

3) Menghafal surah al-Fatihah,

4) Pesan surah al-Fatihah,

5) Lafal huruf hijaiyah dan harokatnya.

c. Pelajaran 3 materi Iman Kepada Allah SWT

1) Yakin Allah SWT itu. ada,

2) Allah SWT. itu esa.

d. Pelajaran 4 materi Jujur dan Percaya Diri

1) Jujur,

2) Percaya diri.

e. Pelajaran 5 materi Bersih itu Sehat

1) Bersuci,

\footnotetext{
${ }^{17}$ Kementrian Pendidikan dan Kebudayaan, Pendidikan Agama Islam Dan Budi Pekerti, (Jakarta: Kementrian Pendidikan dan Kebudayaan, 2013), 1-74.
} 
2) tata cara bersuci,

3) hidup bersih.

f. Pelajaran 6 materi Cinta Nabi dan Rasul

1) Teladan nabi Adam a.s.

2) Teladan nabi Nuh a.s.

3) Teladan nabi Hud a.s.

g. Pelajaran 7 materi Ayo Belajar

1) Semangat belajar nabi Idris a.s.

2) Doa belajar,

3) Membaca dan menulis,

4) Rajin belajar.

h. Pelajaran 8 materi Ayo Belajar Al-Qur'an

1) Lafal surah al-Ikhlas,

2) Hafal surah al-Ikhlas,

3) Pesan surah al-Ikhlas.

i. Pelajaran 9 materi Allah SWT. Maha Kuasa

1) Al-Malik,

2) Dua kalimat syahadat.

j. Pelajaran 10 materi Ayo Kita Solat

1) Salat wajib,

2) Mengaji di sekitar rumah.

k. Pelajaran 11 materi Perilaku Terpuji

1) Berkata yang baik,

2) Hormat dan patuh,

3) Bersyukur,

4) Pemaaf.

\section{Muatan Nilai karakter dalam Buku Siswa PAI}

\section{Pelajaran 1 materi kasih sayang}

Nilai-nilai karakter yang tertuang dalam materi ini antara lain: rasa ingin tahu, peduli sosial, santun, kemandirian, berakhlak mulia, dan peduli lingkungan. Nilai rasa ingin tahu ditunjukkan melalui kisah kasih sayang nabi Muhammad saw kepada umatnya. Cerita yang diambil adalah ketika nabi pulang dari hari raya idul fitri disaat semua anak sedang bahagia beliau melihat seorang anak yatim menangis kemudian beliau menghibur dan mengangkat anak yatim itu menjadi anaknya. Cerita ini menunjukkan 
bahwa pentingnya nilai rasa peduli kepada sesamanya walaupun tidak ada hubungan saudara kita wajib menyayangi terhadap sesamanya. Melalui cerita teladan tersebut siswa dapat mengetahui dan mengagumi sifat kasih sayang nabi kemudian mencontoh/meneladani dengan berbuat baik kepada sesama. Hal ini ditunjukkan dalam kolom

\section{Sikapku}

\section{Aku cinta Rasulullah saw.}

Tugas/latihan yang mencakup nilai karakter peduli sosial dan berakhlak mulia yakni dengan mengamati dan menceritakan gambar menolong teman yang sedang jatuh dari sepeda dan menjenguk teman atau saudara yang sedang sakit. Hal ini ditunjukkan pada gambar di bawah ini.

\section{Ayo Kerjakan}

Amati gambar berikut!
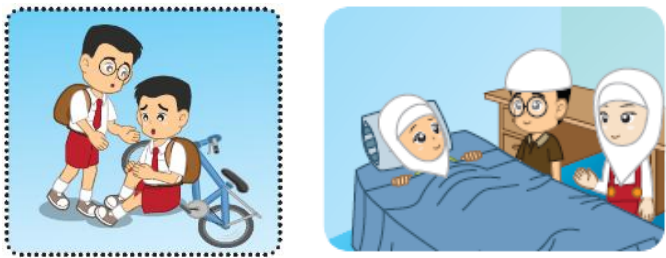

Adapun tugas/latihan yang menunjukkan nilai kemandirian dan bertanggung jawab melalui penilaian diri (self assessement) berupa angket yakni memberi tanda ceklis di dalam kolom ya atau tidak dalam uraian yang menyatakan aku cinta nabi (religius), nabi muhammad teladanku, selalu berbuat baik dan selalu menolong teman (berakhlak mulia).

Sedangkan materi kasih sayang Allah Swt. mengandung nilai rasa ingin tahu dari makna Asmaul khusna melalui penyajian pengetahuan yang jelas dan logis dari makna ar-Rahman dan ar-Rahim. Selain itu nilai berakhlak mulia juga ditunjukkan dari aplikasi makna ar-rahman (maha pengasih) yakni meneladani makna ar-Rahman (sikap saling mengasihi pada sesamanya) dan bersyukur atas apa yang diterima. Gambar yang menunjukkan adalah

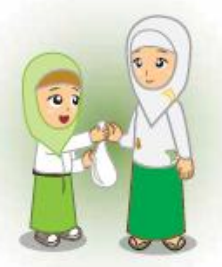


Sedangkan makna ar-Rahim (maha penyayang) yakni meneladani sikap saling menyayangi terhadap semua mahkluk baik sayang kepada diri sendiri, kepada teman dan peduli terhadap alam sekitar. Sikap tersebut merupakan aplikasi dari nilai karakter berakhlak mulia dan santun.

Hal ini dikongkritkan pada contoh gambar dan kolom sikap siswa di bawah ini:

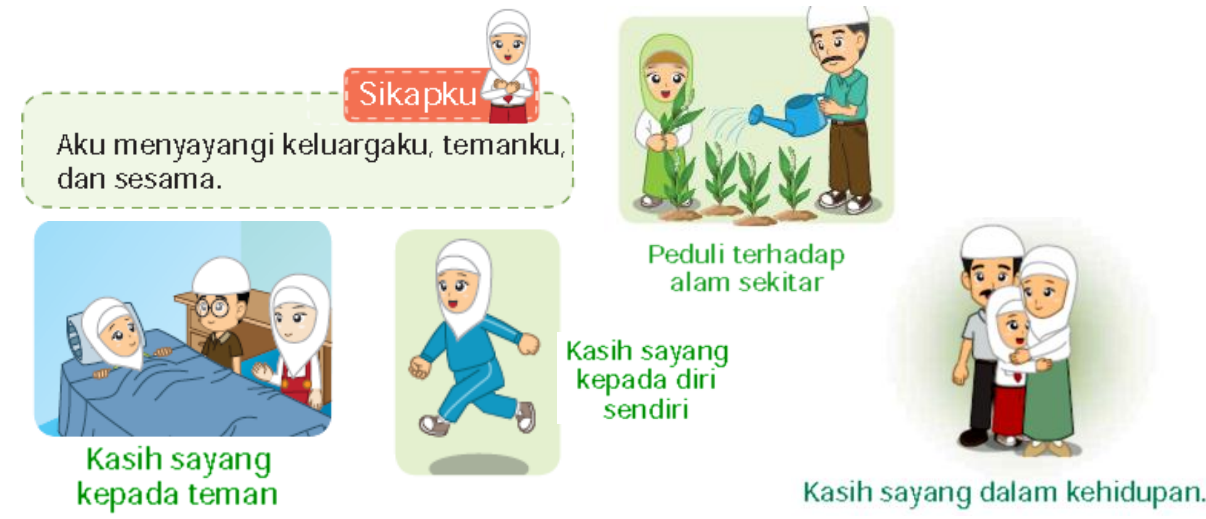

Tugas/latihan yang mencakup nilai karakter rasa ingin tahu dan bertanggung jawab yakni siswa melafalkan ar-Rahman dan ar-Rahim, menceritakan kasih sayang dalam keluarga, mengamati gambar alam semesta dan makhluk hidup semua mendapatkan kasih sayang Allah, mengisi angket self assessement dengan menceklis kolom ya/tidak dan mengisi pertanyaan meliputi pengetahuan siswa tentang menyebutkan arti dari ar-Rahman dan ar-Rahim. Nilai demokratis ditunjukkan pada tugas kelompok mendiskusikan bersama apa yang sebaiknya dilakukan bila temanmu sakit.

\section{Pelajaran 2 materi aku cinta al-Qur'an}

Nilai-nilai karakter yang tertuang dalam materi ini antara lain: religius, gemar membaca, disiplin, beriman, tanggung jawab, percaya diri, rasa ingin tahu dan komunikatif. Nilai religius yang terdapat materi ini terlihat jelas dari judul bab, yakni “aku cinta al-Qur'an" dengan didasari rasa mencintai al-Qur'an maka dengan sendirinya nilai gemar membaca/suka membaca al-Qur'an akan muncul dalam diri siswa. Hal ini ditunjukkan dalam gambar di bawah ini 


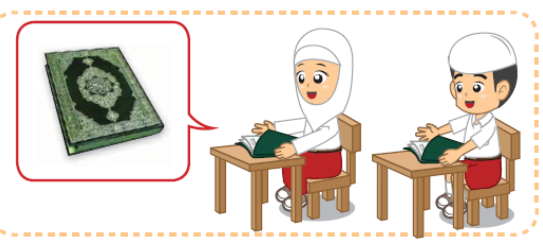

Materi membaca basmalah mengandung nilai religius yang mana siswa diajarkan untuk terbiasa membaca bismillah setiap memulai aktivitas. Ditinjau dari segi visualisasinya, ditunjukkan dengan adanya gambar siswa sedang membaca bismillah ketika akan memulai sesuatu, contoh gambar yang diambil yakni membaca bismillah ketika akan makan.

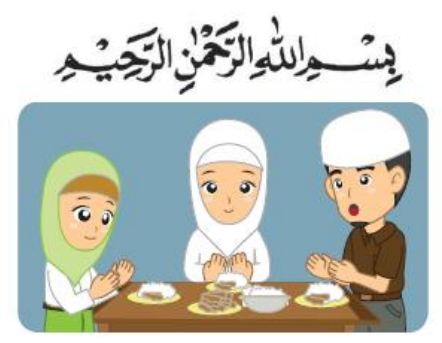

Nilai karakter disiplin dan beriman tercakup dalam materi tersebut, dikatakan disiplin karena siswa (melakukan tindakan) membaca bismillah pada setiap akan melakukan suatu pekerjaan dan dikatakan beriman karena siswa terbiasa membaca doa sebelum melakukan pekerjaan. Visualisasinya ditunjukkan oleh kolom sikapku seperti di samping.

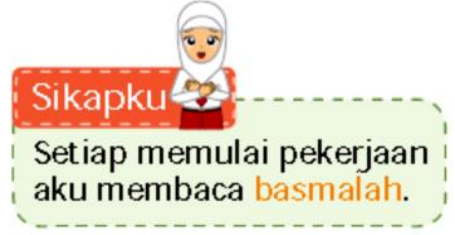

Tugas individu yang mencakup nilai karakter percaya diri dan bertanggung jawab yakni membaca basmalah di depan kelas, mengisi angket self assessement dengan menceklis kolom ya/tidak dan mengisi pertanyaan meliputi aku membaca basmalah sebelum mandi, sebelum berpakaian, sebelum berangkat, dan sebelum belajar. Latihan yang disajikan adalah coba membaca basmalah sebelum menulis.

Nilai karakter melafalkan surah al-Fatihah adalah gemar membaca ditunjukkan dalam kegiatan melafalkan surah al-Fatihah secara bersama kemudian siswa diajak untuk melafalkan sendiri surah al-Fatihah. Nilai tersebut terdapat dalam kolom sikap siswa yakni 


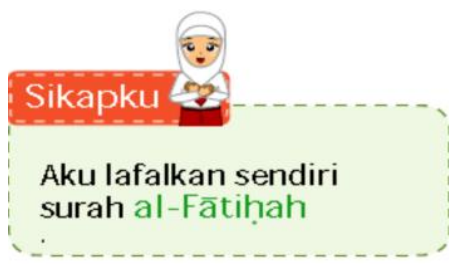

Tugas/kegiatan yang disajikan mengandung nilai gemar membaca dan komunikatif artinya membaca dengan sesama teman/saling menyimak bacaan.

Nilai karakter yang tercantum menghafal surah al-Fatihah ialah nilai tanggung jawab yang mana siswa diharuskan hafal surah al-Fatihah ayat demi ayat. Hal ini ditunjukkan pada kolom sikap siswa yakni

\section{Sikapku le?}

Aku harus hafal surah al-Fatihah.

Tugas/kegiatan yang diberikan adalah menghafal surah al-Fatihah dan dilakukan secara bergantian, merupakan aplikasi dari nilai tanggung jawab dan komunikatif.

Nilai rasa ingin tahu terdapat dalam pembahasan pesan surah alFatihah yang mana siswa dapat mengetahui isi pesan di dalam surah alFatihah. Isi pesan tersebut terkandung nilai religius di dalamnya, yakni agar kita taat dan selalu memohon hanya kepada Allah swt. Hal ini diaplikasikan dengan berakhlak mulia dalam kehidupan bersikap menjalankan perintahnya dan menjauhi larangannya.

\section{Sikapku}

\section{Aku harus berakhlak baik.}

Tugas individu yang mencakup nilai rasa ingin tahu dan bertanggung jawab yakni menyebutkan pesan surah al-Fatihah, mengisi angket self assessement dengan menceklis kolom ya/tidak dan mengisi pertanyaan meliputi hafalan dan pengetahuan tentang pesan surah alFatihah.

Nilai yang terkandung gemar membaca yakni melafalkan huruf hijaiyah dan harokatnya hal ini ditunjukkan pada kolom sikap siswa yang mengungkapkan 


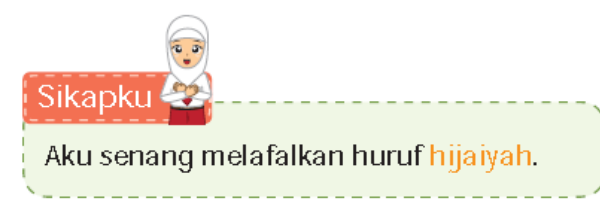

Tugas/latihan yang disajikan juga mengandung nilai rasa ingin tahu dan gemar membaca, yakni dari mengamati huruf hijaiyah dan melafalkan hurufnya secara bergantian, nilai sabar melafalkan huruf hijaiyah perlahan-lahan, dan nilai komunikatif yakni bersama tujuh teman melafalkan huruf hijaiyah secara berurutan.

\section{Pelajaran 3 materi Iman Kepada Allah Swt}

Nilai karakter yang tertuang adalah religius, bersyukur dan rasa ingin tahu. Nilai religius ditunjukkan pada kolom sikap siswa vakni aku percaya dan yakin Allah itu ada dan Allah Maha Esa.

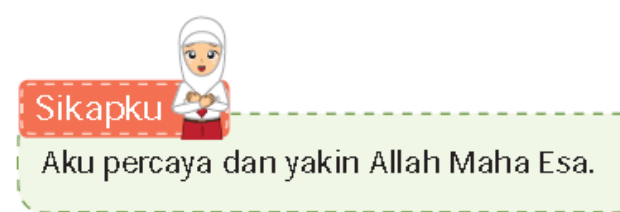

\section{Sikapku}

Aku percaya dan yakin Allah itu ada.

Sedangkan nilai rasa ingin tahu ditunjukkan melalui pengetahuan bahwa Allah menciptakan alam semesta untuk manusia, menciptakan manusia yang lengkap dengan nama dan manfaat setiap anggota tubuhnya, memberikan lingkungan dan keluarga yang bahagia, memberikan guru yang selalu membimbing, serta teman yang baik.
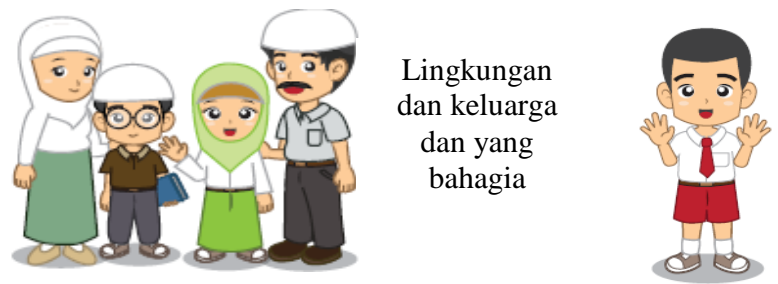

Anggota tubuh yang lengkap dengan nama dan segala manfaatnya
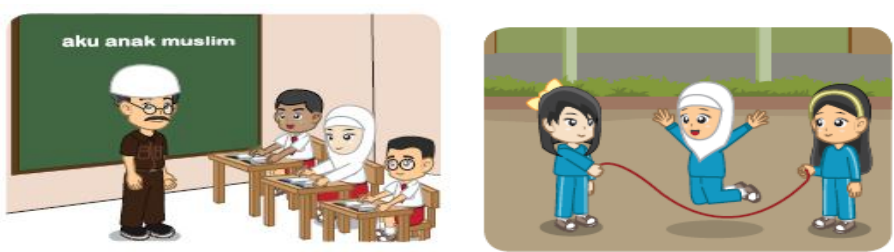

Teman yang baik

Guru yang selalu membimbing 
Nilai bersyukur ditunjukkan pada kolom sikap siswa yakni bersyukur kepada Allah Swt. karena diberi anggota tubuh dan keluarga yang bahagia.

\section{Sikapku \\ Aku bersyukur kepada Allah Swt. diberi keluarga bahagia.}

\section{Sikapku}

Aku bersyukur kepada Allah Swt. karena diberi anggota tubuh.

Tugas atau latihan yang mencakup nilai rasa ingin tahu yakni menyebutkan ciptaan Allah Swt dan menjawab pertanyaan seputar yakin adanya Allah melalui kebesaran akan ciptaan Allah, tentang nama dan manfaat anggota tubuh dan cara menghormati sesama. Nilai bersyukur ditunjukkan melalui penilaian diri berupa angket seputar bersyukur kepada Allah, bersyukur diberi anggota tubuh, punya keluarga, punya teman dan guru.

\section{Pelajaran 4 materi Jujur dan Percaya Diri}

Nilai karakter yang tertuang adalah jujur dan percaya diri. Nilai jujur sebagai implementasi dari sifat shiddiq rasulullah ditunjukkan pada kolom sikap siswa yakni selalu berkata jujur, dengan berbuat jujur akan disayang Allah, disukai guru dan teman. Visualisasinya berupa gambar siswa menjawab pertanyaan guru dengan jujur.

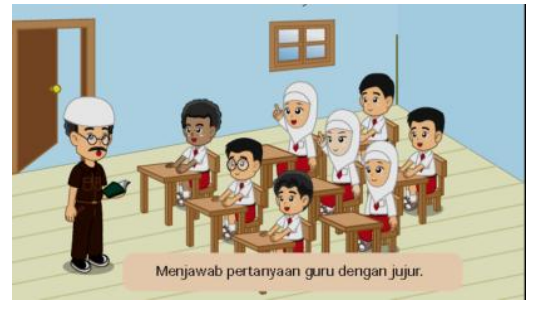

Tugas yang diberikan yakni menyebutkan manfaat berbuat jujur dan menceritakan teman yang berbuat jujur. Mengisi angket penilaian diri tentang selalu jujur dalam mengerjakan ulangan, perkataan, tidak curang dan tidak berbohong. Kemudian mengamati dan menceritakan gambar tentang siswa berbuat jujur. 


\section{Ini bukumu yang kutemukan \\ di lapangan upacara.}

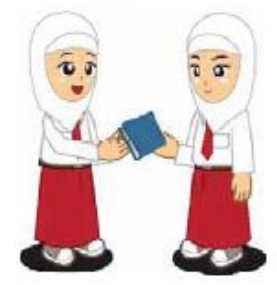

Nilai percaya diri ditunjukkan pada kolom sikap siswa yang yakin akan kemampuan diri sendiri tanpa minder ataupun malu. Contoh gambar yang disajikan yakni siswa tanpa malu memperkenalkan dirinya di depan kelas satu persatu.

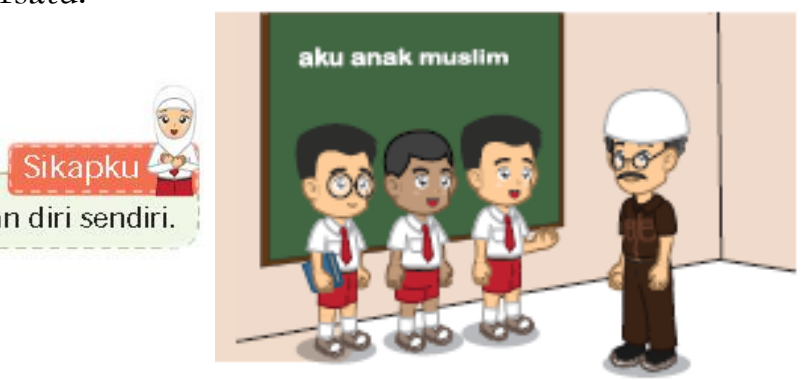

Penilian diri (self assessement) yang disajikan meliputi yakin akan kemampuan diri sendiri dan yakin Allah memberikan kemudahan. Kemudian mengamati gambar siswa yang berani/percaya diri maju kedepan untuk bercerita kepada teman-temanya.

\section{Pelajaran 5 materi Bersih itu Sehat}

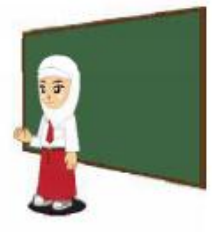

Nilai karakter yang tertuang adalah menghargai kesehatan, religius, disiplin, tanggung jawab, mandiri dan beriman. Nilai religius ditunjukkan sebelum beribadah kita wajib bersuci karena Allah mencintai orang yang bersih dan suci. Nilai rasa ingin tahu ditunjukkan dari pembahasan arti bersuci, macam-macam bersuci (mandi dan istinja'), dan tata cara bersuci (mandi dan istinja') selain itu ditunjukkan 
dalam kolom sikap siswa yang menyatakan bersih itu sehat. Nilai menghargai kesehatan ditunjukkan dalm kolom sikap siswa yakni harus membersihkan badan, pakaian dan tempat salat.

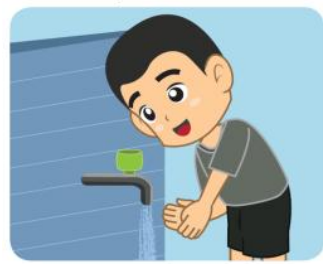

Berwudlu sebelum beribadah
Sikapku

Aku harus membersihkan badan. pakaian, dan tempat șalat

Nilai disiplin dan bertanggung jawab yakni membiasakan hidup bersih baik dari badan (membiasakan mandi dua kali sehari), pakaian, barang-barang, dan tempat baik rumah, tempat ibadah, dan tempat tidur.
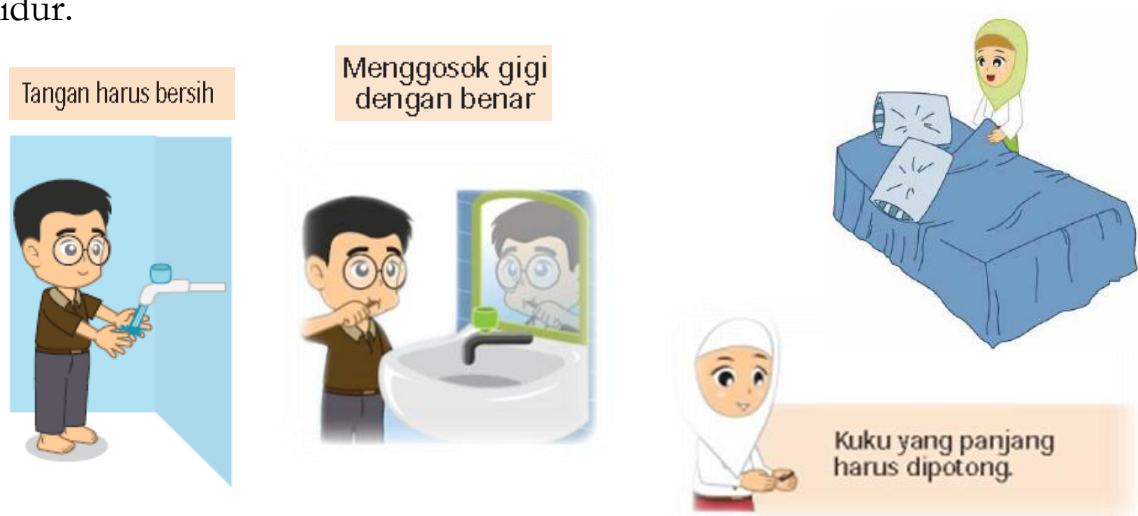

Kuku yang panjang harus dipotong.
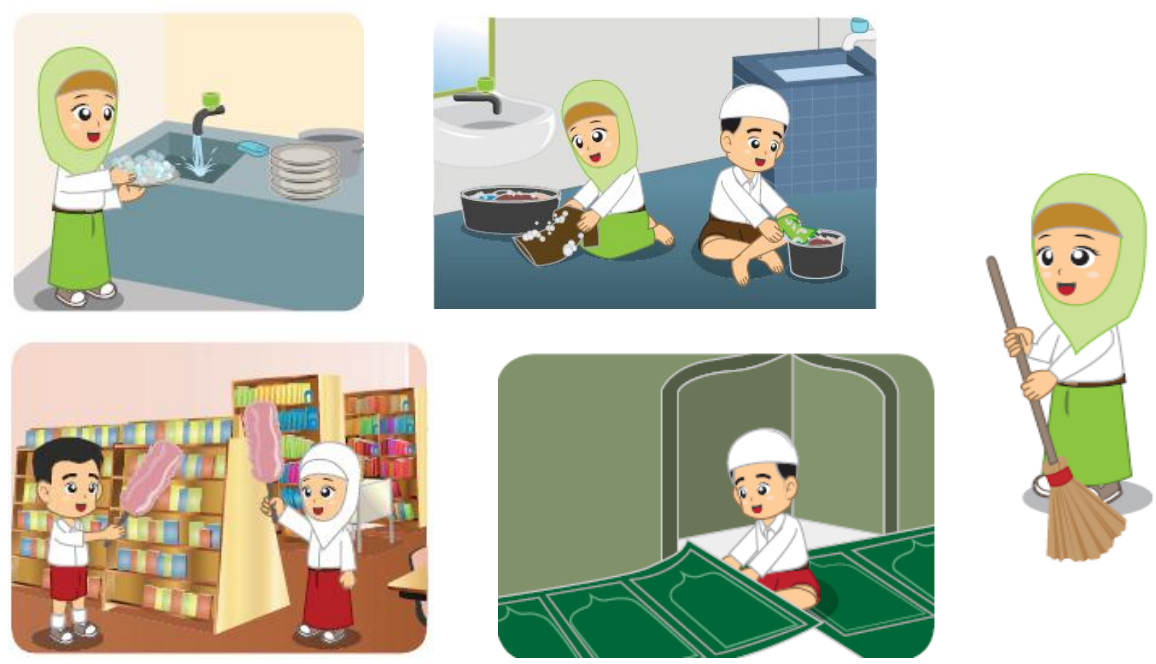
Kemudian nilai berakhlak mulia ditunjukkan dalam kolom sikap siswa yakni membantu orang tua di rumah.

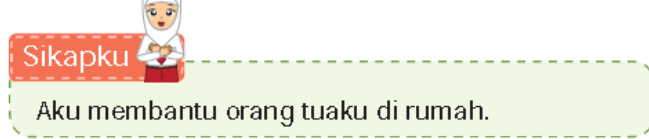

Adapun tugas yang disajikan dari nilai rasa ingin tahu yakni mengamati dan menceritakan gambar tentang bersuci dan mandi, menyebutkan macam-macam bersuci, menyebutkan tata cara mandi, menjawab pertanyaan seputar arti dan macam-macam bersuci. Menceklis tabel penilaian

diri meliputi tahu arti bersuci, arti istinja', dan tahu manfaat mandi.

Tugas atau latihan yang mencerminkan nilai disiplin, tanggung jawab dan mandiri yakni mengamati gambar bersama-sama membersihkan kelas dan dari penilaian diri berupa angket meliputi biasa mandi sendiri setiap hari, bersuci setelah buang air kecil dan besar, membuang sampah pada tempatnya.
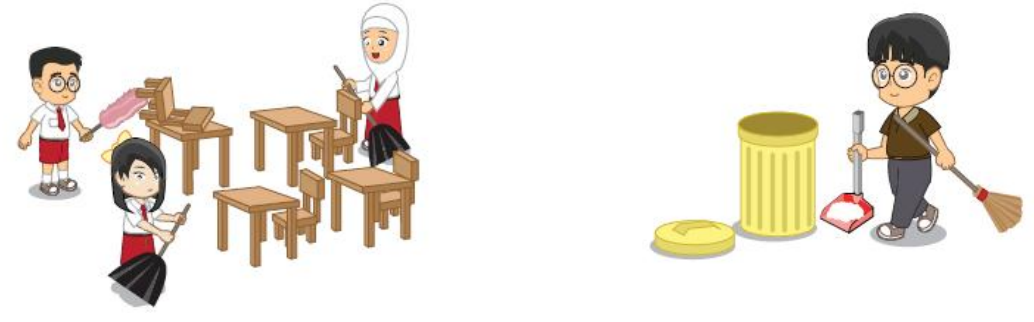

\section{Pelajaran 6 materi Cinta Nabi dan Rasul}

Nilai karakter yang tertuang adalah berakhlak mulia, rasa ingin tahu, kerja keras, sopan santun. Nilai berakhlak mulia dan rasa ingin tahu ditunjukkan dengan cara mencintai nabi yang rasul, mereka mengajarkan manusia berakhlak mulia sehingga mencapai kebahagiaan dunia dan akhirat. Oleh karena itu sebagai kaumnya kita harus meneladani akhlak beliau dari kisah-kisah tauladan. Pada kolom sikap siswa yang meminta maaf apabila berbuat salah dalam hal ini dicontohkan melalui kisah teladan nabi Adam a.s. yang selalu taat kepada Allah Swt. dan meminta maaf/bertaubat bila berbuat salah.

\section{Sikapkı}

Aku meminta maaf apabila berbuat salah.

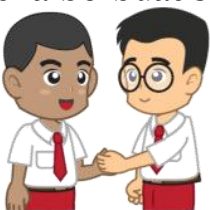


Nilai bekerja keras dan rasa ingin tahu ditunjukkan pada kolom siswa selalu bekerja keras hal ini dicontohkan melalui kisah teladan nabi Nuh a.s. yang taat kepada Allah dan selalu bekerja keras.

\section{Sikapku of}

\section{Aku selalu bekerja keras.}

Kemudian nilai sopan santun dan rasa ingin tahu ditunjukkan pada kolom siswa yang selalu bersikap sopan hal ini dicontohkan melalui kisah teladan nabi Hud a.s. yang memiliki sikap santun, berbudi luhur, dan tidak mudah marah.

\section{Sikapku 20}

\section{Aku selalu bersikap sopan.}

Tugas yang disajikan dari nilai berakhlak mulia (sikap pemaaf) adalah mengamati gambar siswa saling memaafkan, nilai berkerja keras dengan mengamati gambar belajar dengan sungguh-sungguh untuk menggapai cita-citanya, kemudian nilai sopan santun yakni mengamati gambar siswa berpamitan kepada orang tua ketika akan berangkat sekolah.
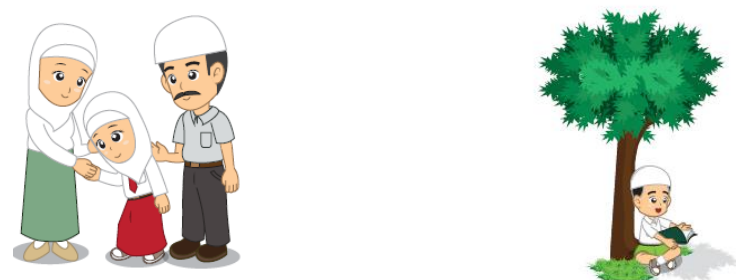

Penilaian diri melalui angket tentang memohon dan meminta maaf jika salah, belajar dan berdoa sungguh-sungguh, berkata sopan, menerima nasihat dan tidak mudah marah. Kemudian berlatih dengan menjawab soal seputar kisah dan sikap nabi Adam, Nuh dan Hud.

\section{Pelajaran 7 materi Ayo Belajar}

Nilai karakter yang tertuang adalah rasa ingin tahu, beriman, religius dan bertaggung jawab. Nilai rasa ingin tahu yang pertama yakni melalui pengetahuan kisah teladan nabi Idris yang pandai karena beliau rajin belajar sejak kecil. Di dalam al-Qur'an pun juga menyuruh kita untuk selalu belajar. Dengan meneladani dua hal tersebut maka siswa akan bersikap selalu rajin dan semangat dalam belajar. Kedua yakni mengenal makna dan doa sebelum dan sesudah makan. 
Nilai beriman ditunjukkan dengan selalu membaca doa sebelum dan sesudah belajar.
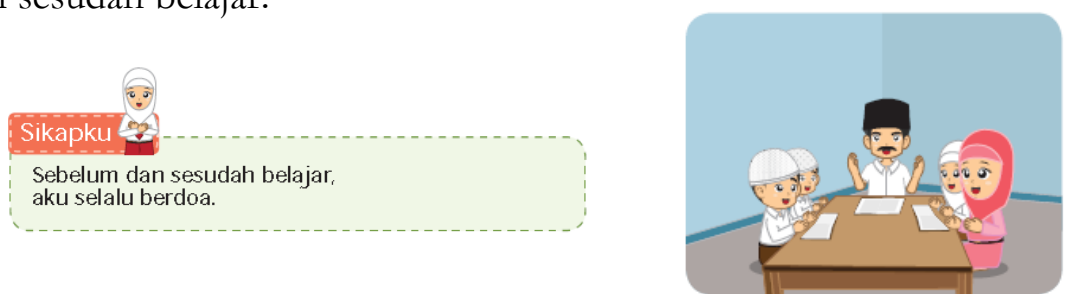

Sedangkan nilai religius terdapat pada kolom sikap siswa percaya dan yakin kepada Allah Swt menciptakan manusia secara sempurna yang disertai akal sehingga dapat membaca dan menulis.

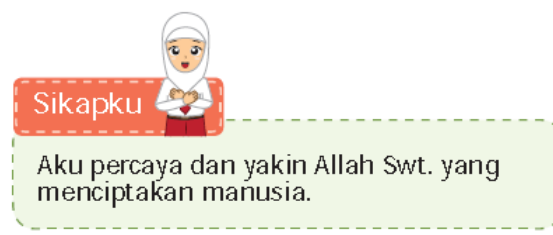

Kemudian nilai tanggug jawab ditunjukkan dengan sikap rajin belajar sebagai implementasi dari pemahaman surah al-Alaq/96 ayat 15, bahwa anak pandai pasti rajin belajar. Visualisasinya ditunjukkan melalui gambar dan kolom sikap siswa.

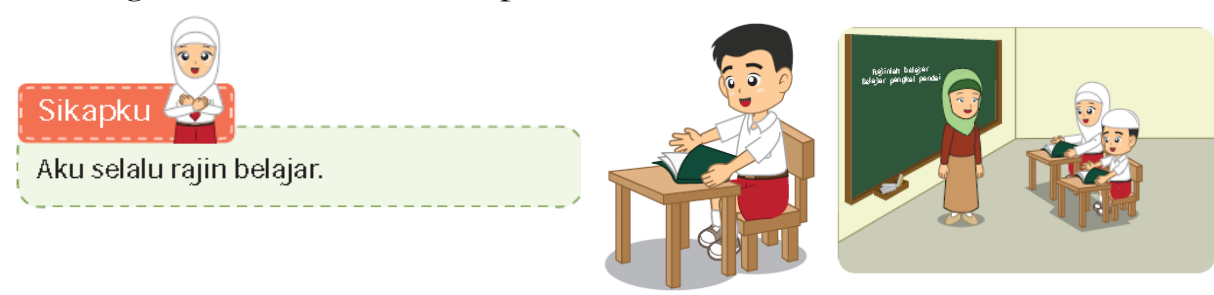

Adapun tugas yang disajikan dari nilai karakter di atas yakni mengamati gambar rajin belajar di kelas bersama teman, bertanya cara belajar yang baik kepada guru. Kemudian melalui penilian diri tentang rajin belajar, hafal doa sebelum dan sesudah belajar beserta artinya, selalu belajar membaca dan menulis. Sedangkan latihannya berupa menjawab soal tentang kisah nabi idris yang rajin belajar, menjawab arti dari doa sebelum dan sesudah belajar.

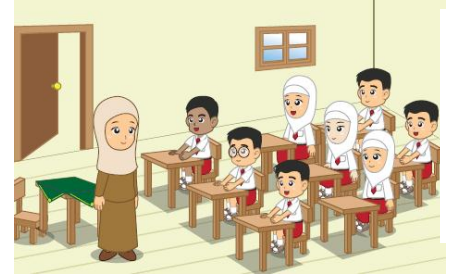

Rajin belajar dan bertanya cara belajar yang baik kepada guru

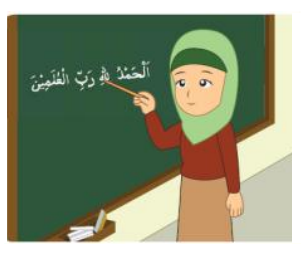

Menjawab makna dari doa sebelum dan sesudah belajar 


\section{Pelajaran 8 materi Ayo Belajar Al-Qur'an}

Nilai karakter yang tertuang adalah gemar membaca, rasa ingin tahu, religius dan berakhlak mulia. Nilai gemar membaca ditunjukkan pada melafalkan surah al-Ikhlas baik dibaca sendiri maupun bersamasama.

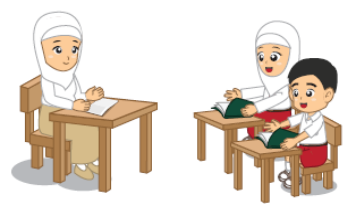

\section{Sikapku}

Aku melafalkan sendiri surah al- Ikhlas.

Nilai rasa ingin tahu ditunjukkan melalui pengetahuan tentang isi pesan surah al-Ikhlas yang mana berisi tentang iman kepada Allah yang maha esa dan hanya kepadanya kita meminta pertolongan, dari pesan surah tersebut ditunjukkan adanya nilai religius yang terkandung, hal ini ditunjukkan dari sikap siswa yakni

\section{Sikapku}

Aku percaya dan yakin Allah Maha Esa.

Nilai tanggung jawab yakni ditunjukkan dari kolom siswa yang harus hafal surah al-Ikhlas. Kemudian melafalkan surah al-Ikhlas dan menunjukkan hafalannya dengan benar dan jelas.

\section{Sikapku}

Aku harus hafal surah al-Ikhlas.

Adapun tugas atau latihan yang diberikan yakni lafalkan, hafalkan dan sebutkan isi pesan surah al-Ikhlas bersama temanmu secara bergantian.

\section{Pelajaran 9 materi Allah Swt. Maha Kuasa}

Nilai karakter yang tertuang adalah religius dan rasa ingin tahu. Nilai rasa ingin tahu dari makna al-Malik (maha raja) dan lafal dua kalimat syahadat. Sedangkan nilai religius terdapat dalam kolom sikap siswa yakni percaya Allah Swt. maha kuasa dan percaya Allah swt sebagai tuhanku dan Muhammad nabiku. 


\section{Sikapku}

Aku percaya Allah Swt. adalah Tuhanku. Muhammad adalah nabi dan rasulku.

\section{Sikapku}

Aku percaya dan yakin Allah Swt. Mahakuasa.

Tugas dan latihan yang mengandung nilai rasa ingin tahu yaitu mengamati gambar alam semesta dan menentukan siapa yang menciptakan.

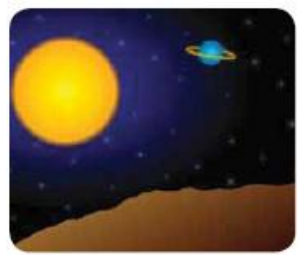

Kemudian mengisi angket penilaian diri tentang arti al-Malik, dapat melafalkan, hafal, mengartikan dua kalimat syahadat, percaya Allah tuhanku dan Muhammad nabiku. Selanjutnya menjawab soal latihan yang membahas tentang makna al-Malik dan dua kalimat syahadat.

\section{Pelajaran 10 Materi Ayo Kita Solat}

Nilai karakter yang tertuang adalah religius, rasa ingin tahu dan tanggung jawab. Nilai rasa ingin tahu dijelaskan pada pengetahuan tentang shalat 5 waktu dalam sehari dan jumlah rokaatnya yang wajib dilakukan oleh umat Islam. Nilai religius ditunjukkan pada kolom sikap siswa yang selalu melakukan shalat 5 waktu dan mengaji bersama teman, orang tua dan guru yang mengajariku

\section{Sikapku}

Aku selalu melakukan salat 5 waktu.

\section{Sikapku}

Aku selalu mengaji bersama teman.

Dari segi visualisasinya ditunjukkan pada gambar salat berjamaah bersama keluarga dan mengaji bersama teman.
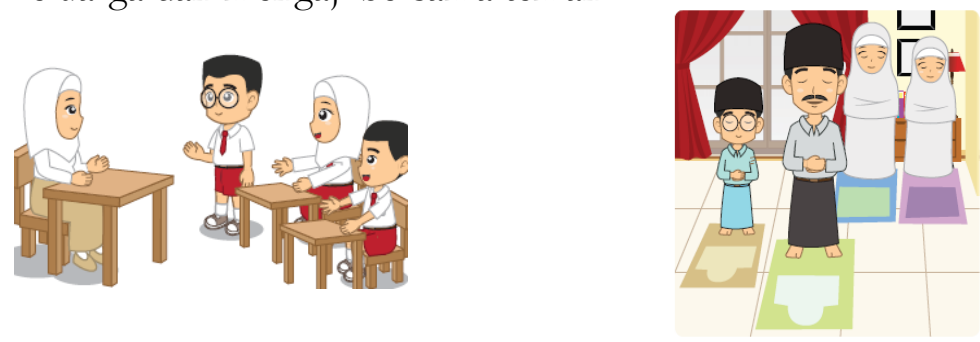
Pemaparan tugas atau latihan yang mengandung nilai rasa ingin tahu ditunjukkan pada tugas menyebutkan salat wajib 5 waktu, penilaian diri melalui angket hafal nama-nama salat dan jumlah rokaatnya, selain itu berlatih menjawab pertanyaan seputar waktu, nama, dan jumlah rakaat salat. Sedangkan yang mengandung nilai religius melalui angket rajin mengaji dan rajin salat. Tugas kelompok mengandung nilai tanggung jawab, kerja sama, komunikatif, dan percaya diri yang mana beberapa siswa mengamati salat dan mengaji di rumah kemudian menceritakan kepada teman di kelas.

\section{Pelajaran 11 materi Perilaku Terpuji}

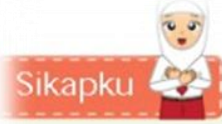

Aku selalu berkata baik dan sopan.

Nilai karakter yang tertuang adalah berakhlak mulia, sopan dan religius. Nilai berakahlak mulia disajikan melalui pembahasan tentang berkata yang baik kepada siapa saja, sopan dan santun, hormat dan patuh baik kepada orang tua maupun guru, sikap pemaaf (apabila ada teman yang berbuat salah kita harus memaafkan). Pemaparan nilai pemaaf ditunjukkan melalui contoh nabi Muhammad pemaaf kepada semua umat manusia. Secara visualisasi nilai di atas disajikan dengan berbagai gambar dan sikap yang harus dilakukan siswa antara lain:

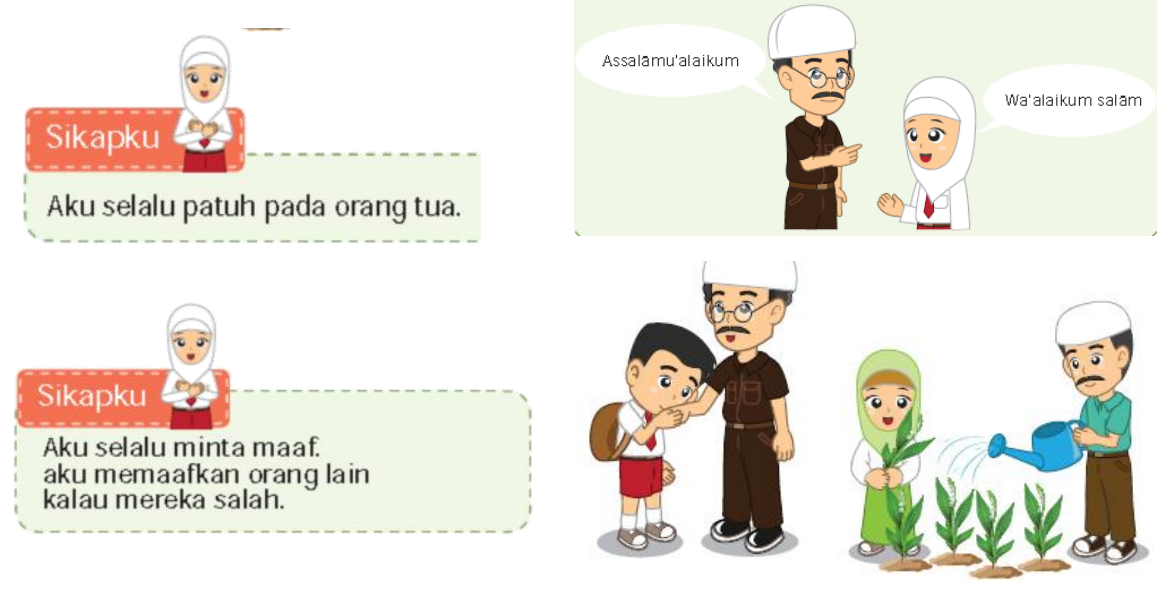


Nilai religius yakni mensyukuri karunia dengan cara mengucapkan alhamdulillah baik setelah mendapatkan sesuatu dan setelah melakukan kegiatan apapun. Contoh yang disajikan yakni berupa gambar siswa mengucap alhamdulilah karena dapat beramal baik dan pada kolom sikap siswa yang mengajarkan untuk selalu bersyukur dengan mengucap alhamdulillah.
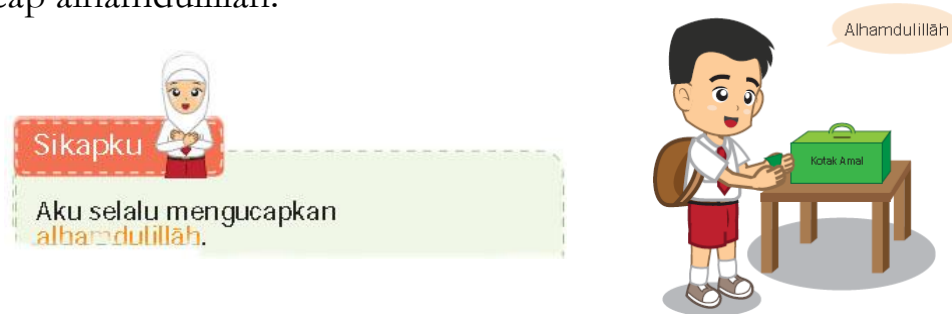

Tugas yang disajikan juga mencerminkan sikap siswa berakhlak mulia, melalui gambar berkata baik yakni mengucapkan salam ketika bertemu guru, gambar hormat dan patuh yakni membantu orang tua membersihkan rumah, gambar bersyukur dengan mengucapkan alhamdulilah setelah belajar dan gambar pemaaf yakni saling memaafkan. Kemudian penilian diri dengan menceklis ya atau tidak sikap selalu berkata benar dan berkata santun, selalu mendengar penjelasan guru, mengerjakan tugas dengan baik, berdoa untuk orang tua, mendengar penjelasan guru, selalu beramal baik dan mengucapkan alhamdulillah, selalu minta dan memberi maaf pada orang lain.

Selanjutnya berlatih dengan mencontohkan berkata baik dan sopan ketika minta izin ke luar kelas, mencontohkan cara minta maaf kepada teman, mempraktekkan sikap sopan kepada guru dan berpamitan kepada orang tua ketika akan berangkat sekolah.

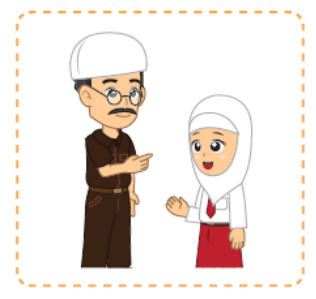

\section{Contohkan cara minta izin pergi ke sekolah kepada orang tua!}

Meminta maaf kepada teman
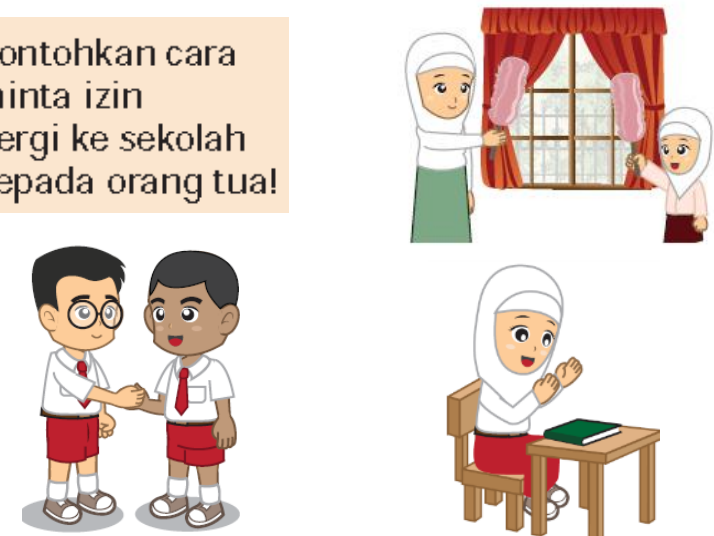


\section{Kesesuaian Nilai Karakter yang tertuang dalam buku siswa dengan KI dan KD}

Dari hasil analisis menunjukkan bahwa nilai-nilai/pendidikan karakter yang tertuang dalam buku siswa kelas 1 SD mata pelajaran Pendidikan Agama Islam dan Budi Pekerti secara keseluruhan sudah sesuai bahkan, terdapat beberapa tambahan nilai karakter yang ditemukan pada pengembangan materi atau proses pembelajaran. Hal ini dapat dilihat secara rinci pada lampiran tabel kesesuain nilai karakter.

Materi yang disajikan dalam buku siswa ini sudah urut sesuai pada urutan $\mathrm{KI}$ dan KD atau perencanaan pembelajaran pada buku guru kelas $1 \mathrm{SD}$ mata pelajaran Pendidikan Agama Islam dan Budi Pekerti yang lengkap dengan metode pembelajaran yang memudahkan pemahaman, media gambar yang menarik dan diselingi dengan lagu-lagu islami yang menyenangkan.

Tetapi menurut pandangan peneliti urutan materi pada pelajaran 2, sub bab E "Lafal Huruf Hijaiyah dan Harokatya" akan lebih baik disajikan terlebih dahulu setelah sub bab A "membaca bismillah" karena menurut pandangan peneliti siswa lebih fasih dalam membaca surah al-Fatihah setelah siswa tersebut mengetahui dan melafalkan huruf-huruf hijaiyah dengan makhroj yang benar.

Selain itu jika dilihat dari segi penyampaian materi atau dalam proses pembelajaran masih ada materi yang tidak tersampaikan dalam proses pembelajaran yang tertulis pada buku guru. Yakni pada pelajaran 2 "Aku cinta Al-Qur'an" pada halaman judul disajikan gambar siswa gemar membaca al-Quran dan kalimat singkat "aku suka membaca al-Qur'an. Al-Qur'an kitab suci umat islam." Harusnya jika dilihat dari KI dan judul materi tersebut, materi ini penting untuk disampaikan kepada siswa sebagai penanaman karakter religius dengan mencintai alqur'an dan rasa ingin tahu dengan mengetahui bahwa al-Qur'an adalah kitab suci umat islam.

Dalam pemberian contoh sudah banyak yang sesuai namun masih terdapat beberapa contoh yang kurang kongkret yang terlihat pada bab 2, sub bab A "Membaca Bismillah" dengan contoh gambar membaca bismillah sesudah makan. Jika dilihat dari judul sub bab tersebut memang sudah sesuai dengan materi, tetapi ketika lebih diteliti kembali pada judul bab materi 2 tentang "Aku cinta Al-Qur'an" akan lebih sesuai lagi jika contoh gambar yang disajikan yakni membaca bismillah sebelum memulai membaca al-Qur'an 
kemudian dilengkapi dengan contoh membaca bismillah ketika akan makan agar pencapaian materi lebih sesuai dengan $\mathrm{KD}$ yang tercantum yakni "Terbiasa membaca basmalah setiap memulai aktivitas".

Pada bab 1 sub bab A "Kasih Sayang Nabi Muhammad SAW" kolom salawat badar dibawah ini:

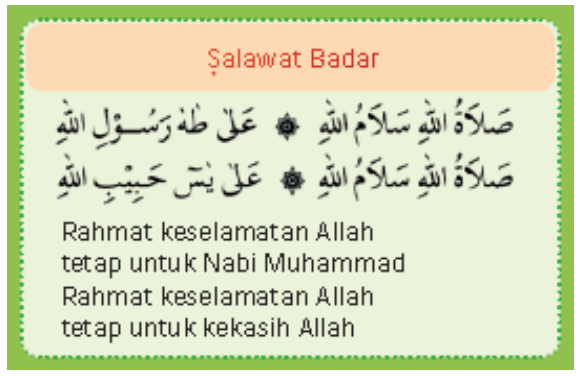

Agar lebih memahamkan siswa arti dari sholawat badar tersebut, sebaiknya arti sholawat diletakkan di bawah tepat pada tiap satu kalimat sholawat yang memiliki arti yang sesuai sehingga siswa dapat lebih mudah memahami arti dari tiap kalimat salawat badar.

Berdasarkan deskripsi terkait kesalahan berbahasa, pada buku siswa kelas 1 SD mata pelajaran Pendidikan Agama Islam dan Budi Pekerti yang diteliti terdapat beberapa kesalahan terkait tanda baca seru. Masih dijumpai kalimat yang menunjukkan perintah melakukan sesuatu tanpa diakhiri dengan tanda seru tetapi diberi tanda baca titik. Salah satu contohnya:

Contoh lain:

\section{Ayo Kerjakan}

Sebutkan pesan-pesan surah al-Fatihah

\section{Ayo Kerjakan \\ Ceritakan manfaat mata, hidung, mulut telinga, dan tangan.}

\section{Kesimpulan}

1. Muatan pendidikan karakter dalam buku siswa Pendidikan Agama Islam dan budi pekerti kelas 1 ada 20 antara lain: rasa ingin tahu, peduli sosial, sopan santun, kemandirian, berakhlak mulia, peduli lingkungan, bersyukur, tanggung jawab, demokratis, religius, gemar membaca, 
komunikatif, sabar, jujur, percaya diri, menghargai kesehatan, disiplin, kerja keras, beriman, kerja sama.

2. Pengelompokkan nilai karakter buku siswa Pendidikan Agama Islam dan Budi Pekerti kelas I adalah sebagai berikut:

a. Nilai karakter dalam hubungannya dengan tuhan: religius, beriman, bersyukur.

b. Nilai karakter dalam hubungannya dengan diri sendiri (Intrapribadi): jujur, disiplin, tanggung jawab, gemar membaca, rasa ingin tahu, menghargai kesehatan, mandiri, percaya diri, cermat, teliti, kerja keras.

c. Nilai karakter dalam hubungannya dengan sesama manusia: sopan santun, peduli sosial, percaya diri, berakhlak mulia, komunikatif.

d. Nilai karakter dalam hubungannya dengan kebangsaan: cinta tanah air

3. Kesesuaian pendidikan karakter dalam buku siswa dengan $\mathrm{KI}$ dan $\mathrm{KD}$ secara keseluruhan sudah sesuai dan lebih disempurnakan lagi dengan tambahan dari pengembangan karakter pada materi dan dalam proses/kegiatan pembelajaran

\section{Daftar Pustaka}

Maksum, Ali. Pluralisme dan Multikulturalisme Pradigma Baru Pendidikan Agama Islam di Indonesia. Malang: Aditya Media Publising, 2011.

Majid, Abdul. Pendidikan Karakter Perspektif Islam. Bandung: PT. Rosda Karya, 2011.

Naim, Ngainun. "Character Building" (optimalisasi peran pendidikan dalam pengembangan ilmu \& pembentukan karakter bangsa). Yogyakarta: Ar-Ruzz Media, 2012.

Kementrian Pendidikan dan Kebudayaan, Pendidikan Agama Islam dan Budi Pekerti. 